\title{
INTERACTION BETWEEN TRADITIONAL AND MODERN SYSTEM OF MEDICINE IN A PRIMITIVE TRIBE OF RAJASTHAN
}

\author{
Pramod Misra, * A.K. Kapoor*
}

Abstract
The development of healing processes and techniques has come a long way
form widely varying tribal pursuits in different communities spread over the globe.
But in course of time they become over shadowed by and subordinated to the
thrusts of western medical assumptions, iniunctions and standards, with the
progress of industrialization. No doubt the latter have proved immensely effective
in dealing with many acute conditions of trauma caused by accidents or case of
sudden onset of physiological disequilibrium. Health and culture are very much
connected with ecology. The traditional health care system and treatment are
based on their deep observation and understanding of nature and environment.
In the present paper an attempt has been made to study the interaction between
traditional and modern system of medicine among Saharia - a primitive tribe of
Rajasthan. Various approaches have been used to collect the data. It has been
observed that in addition to the magico-religious method of treatment, the Saharia
also follow allopathic system of medicines. In the past the Saharia used to
consult only spiritual doctor (janteyar) for treatment of various illnesses. But
now, with the advancement in science and technology faith in supernatural concept
is on decline and the said tribe have developed faith in allopathic doctors also.
Saharia who live in interior areas mainly practice the traditional medical system.
It has been observed that in some villages different treatment (spiritual, herbal
and allopathic) go side by side and tribal have equal faith in all the treatment.
They don't give preference to any particular method of treatment. Few suggestions
have also been made for improving the health status of the Saharia.

* Department of Anthropology, University of Delhi. 


\section{Introduction}

The development of healing processes and techniques has come a long way from widely varying pursuits in different communities spread over the globe. But in course of time they have been overshadowed to the thrust of western medical assumptions, injunctions and standards. No doubt the latter have proved immensely effective in many acute conditions of trauma caused by accidents or the case of sudden onset of physiological disequilibrium.

From an overview of the distribution pattern of the distribution of tribal groups, it becomes evidently clear that that they inhabit ecologically speaking hostile terrains. Invariably these areas are highly endemic zones for malaria and other infectious diseases. Due to non-availability of safe drinking water, proper sanitation and hygiene coupled with several traditional practices, a large number of diseases breed in tribal areas, leading to higher mortality and morbidity (Basu, 1994).

Not much work has been done to study the interaction between traditional and modern system of medicine among Primitive Tribal Groups (PTGs). In the present paper an attempt has been made to study the interaction between traditional and modern system of medicine among Saharia - a Primitive Tribe of Rajasthan. Few suggestions have also been made for improving the health status of the Saharia.

\section{Material and Methods}

Area \& Population- Baran District of Rajasthan is divided into Shahabad and Kishanganj tehsils. Fieldwork was carried out in eight villages of Upreti and eight villages of Taleti during the year 1999-2000. Data was collected from 300 households (150 households of Upreti and 150 households of Taleti). Baran District contributed about 1.84 per cent of the total population of Rajasthan. The Saharia are the only Primitive Tribe of Rajasthan and inhabit in the Shahabad and Kishangani tehsils of Baran District. The total area of Baran District is $2898 \mathrm{sq}$. km. Shahabad has a total area of $1469 \mathrm{sq}$. $\mathrm{km}$ whereas Kishangani has an area of $1429 \mathrm{sq} . \mathrm{km}$. The number of villages in Shahabad tehsil are 236, out of which only 146 are inhabited villages and rest of the villages are uninhabited. The total population in Shahabad tehsil is 83,028 . The population of Saharia in Shahabad tehsil is 28,632 , which forms 34.72 per cent of the Saharia population. The population of Saharia in Kishanganj tehsil is 1,08,345 which forms 17.71 per cent of the Saharia population. The number of villages in Kishangani tehsil are 203, out of which only 171 are inhabited villages. The District Baran contributed 1.84 per cent to the total population of the State. Density of population of Rajasthan works out to be $129 \mathrm{sq} . \mathrm{km}$ whereas 
it is only 116 persons per sq. $\mathrm{km}$ in case of Baran District. According to 1991 census the total population of Saharia in Baran District is 47,822. The Saharia of Rajasthan are concentrated in two tehsils of Shahbad and Kishangani, which also coincide with their respective Panchayat Samitis. The Shahabad and Kishangani tehsil can be divided into two distinct divisions (1) Upreti or Upland and (2) Taleti or Lowland. The Upreti constitutes Kishangani tehsil and the western part of Shahabad tehsil. The remaining part of Shahabad tehsil comes under the classification of Taleti. Saharia do not have disperse pattern of living as found among the Bhils of Southern Rajasthan. They do not have even separate and scattered hamlets. However, the hamlets are slightly far off from the main villages. Each village has a cluster of Saharia families in a separate hamlet known as Saharana. In the Saharana no other caste group live. In the centre of each Saharana they construct umbrella type shelter house, which is called Panchayat Bungalow where all 'Saharia sit together to discuss, gossip and settle their disputes. Shoes are not allowed in the Panchayat Bungalow. Saharia is an endogamous group divided into exogamous clans. From it appears that except Bhilodia, which can be directly linked with Bhils, there are atleast four clans, which appear to bear the names of Raiput clans like Rai Chauhan, Solanki, Devaria, Ragpita Chauhan. Saharia believe in totem and taboos and observe them during rituals and ceremonies of marriage. Marital alliance between the mates of same clan is prohibited by virtue of their affiliation to a common totem. Widow marriage or remarriage called Nata is permissible among the Saharia. The family of Saharia is a nuclear family (98\%). The literacy rate in Saharia (Upreti) is 12.1 per cent as compared to 8.3 per cent in Saharia (Taleti). The religion practiced by Saharia is Hinduism. They worship Hindu gods and goddesses like balaii, bheruii, ambamata, bijamata. They have faith in supernatural powers. They also believe in ghosts and spirits. The fairs, festivals and rituals observed by them come close to Hindu fold. They celebrate Teja Dashmi, Navrat, Makar Sanskranti, Deepawali and Holi with great joy and enthusiasm. Fairs have an important place in the life of Saharia. All Saharia assemble in Sitabari fair. Taking bath in water reservoirs at Sitabari is considered a religious ritual. Attending Sitabari fair is considered a duty. They believe that Mahrishi Valmiki resided over here and Sita also lives here in his Ashram.

\section{Collection of Data}

The intensive and extensive fieldwork was carried out in sixteen villages ${ }^{2}$ of Shahbad Tehsil in the year 1999 - 2000. The primary data was collected from 300 households (150 households of Taleti and 150 households of Upreti) using several tools and techniques such as participant and non-participant observation, schedules, interviews, case studies and focus group discussions (FGD). Secondary data was also collected from census reports, progress reports of Saharia Development Project and other government publications. 


\section{Results and Discussions}

\section{Patterns of Treatment}

\section{Ethnomedical System (Traditional Medical System)}

The Saharia believe that diseases are caused by wrath of gods (devta), goddess (devi), evil spirits and ghosts of the dead. Measles (badi mata) is believed to be causes by the sitla mata. Unsafe delivery is caused by amba mata. Tejaii is a deity related with snakes. Tejaji save the life of Saharia in the forest. Fever is associated with Hanuman, jind or thakur. Typhoid (bade maharai), malaria (chotte maharai), Pneumonia (dibbirog) and tetanus (dhanusban) are believed to be caused by evil spirits and ghosts of the dead. Fits (dakini lagna, bhoot lagna or upri hawa) are supposed to be caused by evil-eye. For treatment of these diseases they consult a janteyar (traditional healer). The janteyar checks the nabj (pulse) of the patient. He also gives spiritual ash (babhooti) to the patients. He also ties tabii (amulets) around the neck and forearm of the patients. An epidemic is also believed to be caused by evil spirits. The Saharia have erected structures represented through various symbols and figures to house the images of these deities. The Saharia also believe that any breach of taboo will anger the deities and the culprit will be punished. To protect from the wrath of supernaturals the Saharia worship these deities during religious festivals, marriage ceremonies, rituals, fairs etc. Offerings of various kinds are also made to them on specific occasions.

This ethnomedical system is more in practice among the Saharia who live in interior villages.

For some ailments, the Saharia use various herbal medicines and healing lotions, which they prepare themselves with the help of various plants, found in the forest. In this way health is deeply interwoven with the forest ecology.

\section{Allopathic Treatment}

In addition to the magico-religious, herbal and indigenous methods of treatment the Saharia also follow allopathic system of medicine. In the past the Saharia always used to consult traditional healer for treatment of sickness. But now, with the advancement, faith in supernatural concept is on decline and the Saharia have faith in allopathic doctors also. But the Saharia who live in interior areas mainly practice ethnomedical system. 61.3 per cent Saharia of Upreti and 58.7 per cent Saharia of Taleti have ever utilized the PHC services. It has been observed that Saharia (Taleti) have been taking treatment from PHC for various diseases such as 
tuberculosis $(40.3 \%)$, skin diseases (3.8\%), malaria $(0.96 \%)$, asthma (1.9\%), typhoid $(0.96 \%)$, nightblindness $(0.96 \%)$, leucorrhoea $(0.96 \%)$, fits $(0.96 \%)$ and accident $(0.96 \%)$ etc. Saharia (Upreti) have been taking treatment from PHC for various diseases such as tuberculosis $(37.8 \%)$, skin diseases $(3.2 \%)$, asthma (1\%) and accident (1\%) etc (Tables 10 \& 11). However it was observed that in most villages (75\%) different treatments (spiritual, herbal and allopathic) go side by side and people have equal faith in all the treatments. They don't give preference to any particular method of treatment. It was told by some of the school teachers that Saharia are not able to purchase medicines due to poverty. Even if they could purchase they cannot continue them for a long period and this results in discontinuance of treatment after a short period. They also change doctors quite often during treatment. At an advanced stage of the disease many a times doctors also fail to treat it. Then the Saharia again have to resort to their traditional methods of treatment or continue to move from one doctor to another and spend a substantial amount of money on treatment. Continuity of sickness for a long time is not uncommon among the Saharia. The longer the period of sickness the higher is the expenses on treatment. According to Doctors of PHC Shahabad the most common ailments for which the Saharia approach the PHC are skin diseases like scabies and eczema, loose motions, malaria, infection of upper respiratory tract, pneumonia, injuries, conjunctivitis and ailments due to malnutrition. Few Saharia have more faith in private practitioner (Unqualified) and prefer to spend money on him rather than going to the government hospital or PHC. The doctors in the PHC Shahabad also told that the Saharia have more faith in injections than in tablets. They want immediate recovery and think it can be provided by an injection. A Saharia would take injections prescribed to him but has a callous attitude towards tablets. However in the interior villages it was found that when a person falls ill initially he consults a traditional healer, locally called janteyar. When the treatment of janteyar did not give any relief and the disease enters it's critical stage then the patient consult an allopathic doctor. The new generation is changing with the advancement in science and technology. But the Saharia of interior villages still adhere to ethnomedical practices of curing diseases. It has been found that only when the janteyar fails to cure the patient and his condition becomes bad to worse then patient is taken to the allopathic doctor for treatment.

Due to inaccessibility of qualified doctors to a majority of Saharia, especially in interior villages and negligence by the doctors the poor Saharia patients prefer to go directly to nearby private unqualified doctors where good treatment at low cost is available.

Saharia respondents were also interviewed for the time frame for treatment of illness, first approach for treatment, consultation with family members, visit to PHC, PHC service utilization, pattern for consultation of health services (traditional vs modern) which have been discussed below: 
Table 1 presents that the Saharia of Taleti (18\%) and Upreti (22\%) don't go for treatment of illness immediately. 26 per cent Saharia of Taleti go within 1-10 days for treatment as compared to Saharia of Upreti (6\%). The Saharia of both Taleti $(42 \%)$ as well as Upreti (56\%) who go for treatment between 11-20 days is higher because the Saharia of these villages (Beelkheradang, Matiakhad, Chaurakhadi, Pathari, Sandhri Khandasehrol, Ghesua, Hatri, Dhikwani and Mahodra) are interiorly located and also due to lack of transport facilities they are not able to go for treatment at Primary Health Centre (PHC) or Sub-Centre (SC). It was also observed that 14 per cent Saharia of Taleti and 16 per cent of Upreti who don't take any treatment were also living in the interior villages.

Table 1: Time Frame for Treatment

\begin{tabular}{|c|l|c|c|c|}
\hline $\begin{array}{c}\text { S. } \\
\text { No. }\end{array}$ & $\begin{array}{l}\text { After how many days you go for } \\
\text { treatment of illness when you } \\
\text { fall ill ? }\end{array}$ & $\begin{array}{c}\text { Saharia of } \\
\text { Taleti }\end{array}$ & $\begin{array}{c}\text { Saharia of } \\
\text { Upreti }\end{array}$ & $\begin{array}{c}\text { Saharia } \\
\text { Total }\end{array}$ \\
\hline 1 & Don't go Immediately & $27(18 \%)$ & $33(22 \%)$ & $60(20 \%)$ \\
\hline 2 & $1-10$ days & $39(26 \%)$ & $09(6 \%)$ & $48(16 \%)$ \\
\hline 3 & $11-20$ days & $63(42 \%)$ & $84(56 \%)$ & $147(49 \%)$ \\
\hline 4 & Don't take any treatment & $21(14 \%)$ & $24(16 \%)$ & $45(15 \%)$ \\
\hline & Total & $150(100 \%)$ & $150(100 \%)$ & $300(100 \%)$ \\
\hline
\end{tabular}

Table 2 presents the first approach for treatment. It has been observed that 47.3 per cent Saharia of Taleti and 28 per cent Saharia of Upreti first approach 'Janteyar' for treatment of illness. Only 22 per cent Saharia (Taleti) and 32.7 per cent Saharia (Upreti) go to PHC/Govt doctor for treatment of illness.

Table 2.

\begin{tabular}{|l|l|l|l|l|}
\hline $\begin{array}{l}\text { S } \\
\text { No. }\end{array}$ & $\begin{array}{l}\text { Whom you approach first } \\
\text { when you fall ill ? }\end{array}$ & $\begin{array}{l}\text { Saharia of } \\
\text { Taleti }\end{array}$ & $\begin{array}{l}\text { Saharia of } \\
\text { Upreti }\end{array}$ & $\begin{array}{l}\text { Saharia } \\
\text { Total }\end{array}$ \\
\hline 1 & $\begin{array}{l}\text { Janteyar'(Traditional } \\
\text { Healer) }\end{array}$ & $71(47.3 \%)$ & $42(28 \%)$ & $113(37.7 \%)$ \\
\hline 2 & PHC/ Govt. Doctor & $33(22 \%)^{\prime}$ & $49(32.7 \%)$ & $82(27.3 \%)$ \\
\hline 3 & Private Doctor (Unqualified) & $26(17.3 \%)$ & $38(25.3 \%)$ & $64921.3 \%)$ \\
\hline 4 & None & $20(13.4 \%)$ & $21(14 \%)$ & $41(13.7 \%)$ \\
\hline 5 & Total & $150(100 \%)$ & $150(100 \%)$ & $300(100 \%)$ \\
\hline
\end{tabular}


Table 3 presents the responsibility for consulting family members before taking any treatment. It has been observed that 78.7 per cent of Taleti and 65.3 per cent of Upreti Saharia consult their family members before taking any treatment.

Table 3 Consultation for Treatment

\begin{tabular}{|c|c|c|c|c|}
\hline $\begin{array}{l}\text { S. } \\
\text { No. }\end{array}$ & $\begin{array}{l}\text { Whether you consult your } \\
\text { family } \begin{array}{l}\text { Saharia of } \\
\text { taking any treatment ? }\end{array}\end{array}$ & $\begin{array}{l}\text { Saharia of } \\
\text { Upreti }\end{array}$ & $\begin{array}{l}\text { Saharia } \\
\text { Total }\end{array}$ \\
\hline 1 & Yes & $118(78.7 \%)$ & $98(65.3 \%)$ & $216(72 \%)$ \\
\hline 2 & No & $32(21.3 \%)$ & $52(34.7 \%)$ & $84(28 \%)$ \\
\hline 3 & Total & $150(100 \%)$ & $150(100 \%)$ & $300(100 \%)$ \\
\hline
\end{tabular}

From Tables $(4,5 \& 6)$ it can be observed that 60 per cent of the Saharia have ever utilised the PHC services. But the Saharia of both Taleti (58\%) and Upreti (64\%) were not satisfied with the facilities available at the PHC. 67 per cent Saharia (Taleti \& Upreti) said that free medicines are not available at PHC. 32 per cent Saharia of Upreti said that free medicines are available at PHC but stated that doctors give prescription on paper only and patients were not given any medicine from PHC. Under these circumstances the Saharia consult Private doctor (Unqualified) who gives proper treatment. The Private doctor charges fees for diagnosis and medicines. It may be mentioned here that only 58.7 per cent Saharia of Taleti and 61.3 per cent Saharia of Upreti have ever used the PHC services.

\section{Table 4 Visit to PHC by Saharia}

\begin{tabular}{|c|c|c|c|c|}
\hline $\begin{array}{c}\text { S. } \\
\text { No. }\end{array}$ & $\begin{array}{c}\text { Have you ever visited } \\
\text { PHC ? }\end{array}$ & Saharia of Taleti & $\begin{array}{c}\text { Saharia of } \\
\text { Upreti }\end{array}$ & $\begin{array}{c}\text { Saharia } \\
\text { Total }\end{array}$ \\
\hline 1 & Yes & $88(58.7 \%)$ & $92(61.3 \%)$ & $180(60 \%)$ \\
\hline 2 & No & $62(41.3 \%)$ & $58(38.7 \%)$ & $120(40 \%)$ \\
\hline & Total & $150(100 \%)$ & $150(100 \%)$ & $300(100 \%)$ \\
\hline
\end{tabular}


Table 5. Satisfaction with the Services of PHC

\begin{tabular}{|c|c|c|c|c|}
\hline $\begin{array}{c}\text { S. } \\
\text { No. }\end{array}$ & $\begin{array}{c}\text { Are you satisfied with } \\
\text { the services of PHC? }\end{array}$ & Saharia of Taleti & $\begin{array}{c}\text { Saharia of } \\
\text { Upreti }\end{array}$ & $\begin{array}{c}\text { Saharia } \\
\text { Total }\end{array}$ \\
\hline 1 & Yes & $63(42 \%)$ & $54(36 \%)$ & $117(39 \%)$ \\
\hline 2 & No & $87(58 \%)$ & $96(64 \%)$ & $183(61 \%)$ \\
\hline 3 & Total & $150(100 \%)$ & $150(100 \%)$ & $300(100 \%)$ \\
\hline
\end{tabular}

Table 6. Availability of Free Medicine at PHC

\begin{tabular}{|c|c|c|c|c|}
\hline $\begin{array}{c}\text { S. } \\
\text { No. }\end{array}$ & $\begin{array}{c}\text { Is free medicine } \\
\text { available at PHC? }\end{array}$ & Saharia of Taleti & $\begin{array}{c}\text { Saharia of } \\
\text { Upreti }\end{array}$ & $\begin{array}{c}\text { Saharia } \\
\text { Total }\end{array}$ \\
\hline 1 & Yes & $51(34 \%)$ & $48(32 \%)$ & $99(33 \%)$ \\
\hline 2 & No & $99(66 \%)$ & $102(68 \%)$ & $201(67 \%)$ \\
\hline 3 & Total & $150(100 \%)$ & $150(100 \%)$ & $300(100 \%)$ \\
\hline
\end{tabular}

From Tables $(7,8 \& 9)$ it can be observed that if the Saharia are not cured by janteyar then they consult PHC or Private doctor (Unqualified). This percentage was found to be higher among the Saharia of Upreti (7.4.7\%). 38 per cent Saharia of Taleti said that they will not consult PHC or Private doctor if they are not cured by the janteyar and they will stop taking any treatment (Table 7). Mostly Saharia of Taleti (54.6\%) and of Upreti (35.3\%) told that if they are not cured by janteyar then they go to PHC/Private doctor after 10 to 20 days. It has been observed that mostly Saharia don't consult allopathic Doctor immediately after illness. Only 8 per cent Saharia of Taleti and 25.3 per cent of Upreti said that they consult PHC/Private doctor immediately if they are not cured by the 'Janteyar' (Table 8). When Saharia are not cured by the PHC or Private Doctor then they revert back to janteyar for treatment. The percentage of Saharia of Taleti who revert back to janteyar was 58 per cent as compared to Upreti (27.3\%) (Table 9). This percentage was higher in interior villages because Saharia of older generation adhere to old practices of curing diseases besides taking allopathic treatment also. 
Table 7 Pattern for Consultation of Health Services (Traditional vs Modern) : Curing Practices by janteyar or PHC/ Private Doctors

\begin{tabular}{|c|c|c|c|c|}
\hline $\begin{array}{c}\text { S. } \\
\text { No. }\end{array}$ & $\begin{array}{c}\text { If not cured by janteyar } \\
\text { whether you consult } \\
\text { PHC/Private Doctor } \\
\text { (Unqualified)? }\end{array}$ & Saharia of Taleti & $\begin{array}{c}\text { Saharia of } \\
\text { Upreti }\end{array}$ & $\begin{array}{c}\text { Saharia } \\
\text { Total }\end{array}$ \\
\hline 1 & Yes & $93(62 \%)$ & $112(74.7 \%)$ & $205(68.3 \%)$ \\
\hline 2 & No & $57(38 \%)$ & $38(25.3 \%)$ & $95(31.3 \%)$ \\
\hline & Total & $150(100 \%)$ & $150(100 \%)$ & $300(100 \%)$ \\
\hline
\end{tabular}

Table 8 Pattern for Treatment of Modern Health Services : Time Framework

\begin{tabular}{|c|c|c|c|c|}
\hline $\begin{array}{c}\text { S. } \\
\text { No. }\end{array}$ & $\begin{array}{c}\text { If yes, after how many days } \\
\text { you go to PHC/Private } \\
\text { Doctor (Unqualified) for } \\
\text { treatment? }\end{array}$ & Saharia of Taleti & $\begin{array}{c}\text { Saharia of } \\
\text { Upreti }\end{array}$ & $\begin{array}{c}\text { Saharia } \\
\text { Total }\end{array}$ \\
\hline 1 & Immediately & $12(8 \%)$ & $38(25.3 \%)$ & $50(16.7 \%)$ \\
\hline 2 & $1-10$ days & $28(18.7 \%)$ & $42(28 \%)$ & $70(23.3 \%)$ \\
\hline 3 & $11-20$ days & $82(54.6 \%)$ & $53(35.3 \%)$ & $135(45 \%)$ \\
\hline 4 & $21-30$ days & $28(18.7 \%)$ & $17(11.4 \%)$ & $45(155)$ \\
\hline 5 & Total & $150(100 \%)$ & $150(100 \%)$ & $300(100 \%)$ \\
\hline
\end{tabular}

Table 9 Pattern for Curing Practices of Modern Health Services vs Traditional System : Attitudes towards Traditional Healing Practices

\begin{tabular}{|c|c|c|c|c|}
\hline $\begin{array}{c}\text { S. } \\
\text { No. }\end{array}$ & $\begin{array}{c}\text { If you are not cured by } \\
\text { PHC/Private Doctor } \\
\text { (Unqualified) whether } \\
\text { you revert back to } \\
\text { janteyar for treatment ? }\end{array}$ & $\begin{array}{c}\text { Saharia of } \\
\text { Taleti }\end{array}$ & $\begin{array}{c}\text { Saharia of } \\
\text { Upreti }\end{array}$ & $\begin{array}{c}\text { Saharia } \\
\text { Total }\end{array}$ \\
\hline 1 & Yes & $87(58 \%)$ & $41(27.3 \%)$ & $128(42.7 \%)$ \\
\hline 2 & No & $63(42 \%)$ & $109(72.7 \%)$ & $172(57.3 \%)$ \\
\hline 3 & Total & $150(100 \%)$ & $150(100 \%)$ & $300(100 \%)$ \\
\hline
\end{tabular}


It has been found that out of a population of 5675 among Saharia of Taleti (8 villages) there were 1435 (25.3\%) sickness cases whereas in Upreti (8 villages) the number of sickness cases were $816(22.8 \%)$ out of a population of 3583 as reported by the medical doctors at PHC. It is to be mentioned here that the data was collected from 104 sickness cases in Taleti and 95 sickness cases in Upreti. Out of 104 sickness cases in Taleti, 9.6 per cent patients were taking herbal treatment, 29.8 per cent patients were taking treatment spiritual (janteyar) treatment, 52.9 per cent were consulting $\mathrm{PHC}$ and 7.7 per cent were not taking any treatment. Out of 95 sickness cases in Upreti, 10.5 per cent patients were taking herbal treatment, 24.2 per cent patients were taking spiritual treatment (ianteyar), 43.1 per cent were consulting PHC and 22.2 per cent were not taking any treatment (Tables $10 \& 11$ ).

From Tables $10 \& 11$ it can be stated that the incidence of tuberculosis $(60.8 \%)$ is very high among the Saharia. This is mainly because of their low living standard, poor personal hygiene, smoking and drinking habits and other social/ environmental conditions. The incidence of skin diseases like scabies (dad) and eczema (khujali) is also high ( 11.5 per cent in Taleti and 16.8 per cent in Upreti) due to unhygienic living conditions. Other diseases prevalent among Saharia are nightblindness (ratondi), malaria (chotte maharai), fits (dakini lagna or bhoot lagna or upri hawa), typhoid (bade maharai) diarrhoea (ulti-dast), stones (pathar). During the fieldwork it was found that for snake bite cases Saharia always consulted janteyar because they think that doctors are helpless in curing snake bites and they can do anything. The Saharia of Taleti (59.6\%) and Upreti (62.1\%) who were suffering from TB (age ranges from 30-55 years) were found attending TB Control Camp which is held on 23rd of every month at Shahabad. It shows that the new generation is changing with modern times. 
Table 10 Name of Diseases and Types of Treatment Followed by Saharia of Taleti

\begin{tabular}{|c|c|c|c|c|c|c|}
\hline \multirow[t]{2}{*}{$\begin{array}{l}\text { S. } \\
\text { No }\end{array}$} & \multirow[t]{2}{*}{$\begin{array}{l}\text { Name of } \\
\text { Disease }\end{array}$} & \multirow[t]{2}{*}{$\begin{array}{c}\text { Number of } \\
\text { Cases }\end{array}$} & \multicolumn{3}{|c|}{ Types of Treatment } & \multirow[t]{2}{*}{$\begin{array}{l}\text { No } \\
\text { Treat- } \\
\text { ment }\end{array}$} \\
\hline & & & Herbal & $\begin{array}{l}\text { Spiritual } \\
\text { janteyar }\end{array}$ & Allopathic & \\
\hline 1 & $\begin{array}{l}\text { Tuberculosis } \\
\text { (TB) }\end{array}$ & $62(59.6 \%)$ & $4(3.8 \%)$ & $12(11.5 \%)$ & $\begin{array}{c}42 \\
(40.3 \%) \\
\end{array}$ & $4(3.8 \%)$ \\
\hline 2 & $\begin{array}{c}\text { Skin diseases } \\
\text { (Scabies, } \\
\text { Eczema) }\end{array}$ & 12 (1 1.5\%) & $2(1.9 \%)$ & $4(3.8 \%)$ & $4(3.8 \%)$ & $2(1.9 \%)$ \\
\hline 3 & $\begin{array}{c}\text { Malaria } \\
\text { /Fever }\end{array}$ & $4(3.8 \%)$ & --- & $3(2.8 \%)$ & $1(0.96 \%)$ & \\
\hline 4 & Asthma & $3(2.8 \%)$ & --. & $1(0.96 \%)$ & $2(1.9 \%)$ & $\ldots$ \\
\hline 5 & Typhoid & $5(4.8 \%)$ & $1(0.96 \%)$ & $3(2.8 \%)$ & $1(0.96 \%)$ & $\ldots$ \\
\hline 6 & Snake bite & $2(1.9 \%)$ & $\ldots$ & $2(1.9 \%)$ & -.. & $\ldots$ \\
\hline 7 & $\begin{array}{c}\text { Night- } \\
\text { blindness }\end{array}$ & $4(3.8 \%)$ & $1(0.96 \%)$ & $2(1.9 \%)$ & $1(0.96 \%)$ & $\ldots$ \\
\hline 8 & Leucorhoea & $4(3.8 \%)$ & $1(0.96 \%)$ & $1(0.96 \%)$ & $1(0.96 \%)$ & $\begin{array}{c}1 \\
(0.96 \%)\end{array}$ \\
\hline 9 & Fits & $3(2.8 \%)$ & --- & $2(1.9 \%)$ & $1(0.96 \%)$ & $\ldots$ \\
\hline 10 & Stones & $2(1.9 \%)$ & $\therefore$ & $-\cdots$ & $1(0.96 \%)$ & $1(0.96 \%)$ \\
\hline 11 & $\begin{array}{c}\text { Diarrhoea } \\
\text { (cough-cold } \\
\text { headache \& } \\
\text { vomiting) }\end{array}$ & $2(1.9 \%)$ & $1(0.96 \%)$ & $1(0.96 \%)$ & 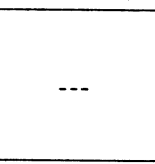 & $\ldots$ \\
\hline 12 & Accident & $1(0.96 \%)$ & --- & $-\cdot$ & $1(0.96 \%)$ & $\ldots$ \\
\hline & Total & 104 (100\%) & $10(9.6 \%)$ & $31(29.8 \%)$ & $\begin{array}{c}55 \\
(52.9 \%)\end{array}$ & $8(7.7 \%)$ \\
\hline
\end{tabular}

The Saharia have identified some diseases like fits, snakebite, typhoid, diarrhoea, $T B$, skin diseases, malaria/fever etc., for which they mostly consult janteyar. If the janteyar fails to cure the patient only then they go to $\mathrm{PHC}$ for treatment. 
Table 11 Name of Diseases and Types of Treatment Followed by Saharia of Upreti

\begin{tabular}{|c|c|c|c|c|c|c|}
\hline \multirow[t]{2}{*}{$\begin{array}{l}\text { S. } \\
\text { No }\end{array}$} & \multirow{2}{*}{$\begin{array}{l}\text { Name of } \\
\text { Disease }\end{array}$} & \multirow{2}{*}{$\begin{array}{c}\text { Number of } \\
\text { Cases }\end{array}$} & \multicolumn{3}{|c|}{ Type of Treatment } & \multirow[t]{2}{*}{$\begin{array}{c}\text { No } \\
\text { Treatment }\end{array}$} \\
\hline & & & Herbal & $\begin{array}{l}\text { Spiritual } \\
\text { janteyar }\end{array}$ & Allopathic & \\
\hline 1 & Tuberculosis (TB) & $59(62.1 \%)$ & $6(6.3 \%)$ & $7(7.4 \%)$ & $36(37.9 \%)$ & $10(10.5 \%)$ \\
\hline 2 & $\begin{array}{l}\text { Skin diseases } \\
\text { (Scabies, } \\
\text { Eczema) }\end{array}$ & $16(16.8 \%)$ & --- & $4(4.2 \%)$ & $3(3.2 \%)$ & $9(9.5 \%)$ \\
\hline 3 & Malaria /Fever & $3(3.2 \%)$ & $\cdots$ & $3(3.2 \%)$ & $\cdots$ & $\ldots$ \\
\hline 4 & Asthma & $1(1 \%)$ & 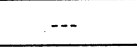 & $\cdots$ & $1(1 \%)$ & $\ldots$ \\
\hline 5 & Typhoid & $3(3.2 \%)$ & $-\cdots$ & $3(3.2 \%)$ & $-\cdots$ & $\ldots$ \\
\hline 6 & Snake bite & $1(1 \%)$ & --- & $1(1 \%)$ & $--\cdot$ & $\cdots$ \\
\hline 7 & Nightblindness & $2(2.1 \%)$ & $2(2.1 \%)$ & -- & -- & $\ldots$ \\
\hline 8 & Leucorrhoea & $1(1 \%)$ & -.- & -.- & $\because-$ & $1(1 \%)$ \\
\hline 9 & Fits & $3(3.2 \%)$ & --- & $3(3.2 \%)$ & $\cdots$ & $\ldots$ \\
\hline 10 & Stones & $1(1 \%)$ & --- & -- & --. & $1(1 \%)$ \\
\hline 11 & $\begin{array}{l}\text { Diarrhoea (cough- } \\
\text { cold, headache\& } \\
\text { vomiting) }\end{array}$ & $4(4.2 \%)$ & $2(2.1 \%)$ & $2(2.1 \%)$ & -- & \\
\hline \multirow[t]{2}{*}{12} & Accident & $1(1 \%)$ & $\cdots$ & --- & $1(1 \%)$ & $\ldots$ \\
\hline & Total & $95(100 \%)$ & $10(10.5 \%)$ & $23(24.2 \%)$ & $41(43.1 \%)$ & $21(22.2 \%)$ \\
\hline
\end{tabular}

However in case of accident they consult an allopathic doctor for getting treatment at the PHC because they think that janteyar cannot cure it.

\section{Case Studies with reference to Ethnomedical System of Treatment}

The following case studies will reflect the interaction of traditional and modern health care system emphasizing on socio-cultural perspective.

Case Study 1 :- Kailash, a resident of Khandasehrol, a female aged 24 years, is suffering from upri hawa (Fits). According to her husband, she was taken to janteyar 
for treatment but she did not recover from illness. For the last three days she was screaming, dancing, shouting and singing. Now she is taken to Baran for treatment. According to Kailash's husband there are cases of bhoot lagna or upri hawa (fits) in which the person starts singing, dancing and shouting. Then he/she is taken to janteyar one day before poornamasi (full moon day) or a day before amavasya (of Chaudas) then janteyar gives him/her the treatment. The janteyar gives jhada by taking bird feathers or plant twigs. The janteyar takes some maize grains in his hand chants some mantra and then goes in trance. His body starts shivering and then he tells the cause of the ailment. He tells the name of the deity which is angry with the sick person and tells the person to made offerings to that particular deity. Only then the sick person will be cured. The janteyar is given ghee, coconut and sugar. The janteyar doesn't take any money because if he takes money his power will be finished. The people in interior villages are more superstitious. They will leave the settled colony if four to five deaths occur in the saharana.

Case Study II :- Kanwar Lal, aged 44 years, a resident of village Beelkhera Dang, told that "I was having fever and initially I thought that there was no need of consulting an allopathic doctor because my condition was not serious. I consulted a janteyar for treatment. But when my condition started deteriorating slowly then I rushed to $\mathrm{PHC}$ at Shahabad and I was given prescription on paper only and was not given any medicine from PHC. Then I stopped going to PHC at Shahabad and now I am going to Sipri in M.P. for getting treatment at a hospital". Kanwarlal further mentioned that "at PHC the doctor give prescription on paper only. The patients were not given any medicine and the villagers are not happy with the services available at PHC. There are cases of fits prevalent in the village. For fits a janteyar is consulted. The janteyar goes, in trance. His body starts shivering rapidly and the devi or devta comes to him then he explains the cause of illness and tells the patient to made offering to a particular deity. The deities who come to him are mainly thakur, jind, khains, bheran, kali and bijasun mata. If the deity does not come to him then it means the patient will die after some time".

Case Study III :- Shravan, aged 35, a resident of village Pathari, narrates "when a child dies while taking milk or during breast feeding, it is believed to be caused by a ghost known as kaccha machan. The dead body of the child is kept in a place, digged and then covered with mud. For avoiding such death the janteyar ties a black thread around neck and forearm of the children (band lagana). It protects the child from evil-eye".

Case Study IV:- Man Singh, aged 55 years, a resident of Khusalpura village, narrates "I am having infection in the eyes. I am following the indigenous treatment for this disease and I found the treatment very effective. He mentioned that the 
paste of leaves of bamoor tree if applied on the eyes or the milk of goat is put as eye drops for one week then eye infection is cured".

Case Study V :- Chaita, aged 32 years, a resident of Shahpur is suffering from tuberculosis for the last three years. She describes "I went to PHC Shahabad for medical check up three years back. But I did not followed the entire course. After one year my condition became serious then I consulted a private doctor (Unqualified) but there was no improvement in my condition." She further mentioned "there are no medicines at PHC. A TB control camp is held at Shahabad on 23rd of every month. Initially I used to attend TB control camp for three to four months but after that I stopped going to attend the TB camp. Then I went to hospital at Baran. The facilities are good at Baran. There is an X-ray machine also. I was admitted at Baran for three months and now I am perfectly all right. Medical facilities are not good at PHC Shahabad. There is an X-ray machine but it is not working and doctors also sometimes scold the patients and then they stop going to PHCs. Then the patients consult private doctors for treatment but it requires money and they cannot afford to consult Private Doctor every time. Then they go to bigger hospitals at Baran or Kota. The life of poor people is like hell. She cried 'Hamari koi sunwai nahi hai' (No body listens to us)".

Case Study VI : - Raghubir, aged 37 years, is residing in the village Faredua. He is suffering from night blindness (ratondi). He narrates "Initially I consulted a janteyar for treatment. But there was no improvement in my condition then I went to Shahabad for treatment where I was told to go to Kota to get treatment in the big hospital. In all this process I have already spent a lot of money." He further said "when janteyar fails to cure the disease then we consult private doctor or go to $\mathrm{PHC}$ and even if the doctors at PHC fails to bring any improvement in the condition of the sick persons then we go to Baran or Kota for treatment".

Case Study VII :- Dharamieet, aged 35 years, lives in the village Dhikwani. His wife is suffering from T.B. According to him "there is no proper arrangement for treatment in villages. If any one has any trouble all of sudden, he or she is taken to Shahabad PHC in a bullock cart where many a times doctors refuse to see the patient. Then the compounder who asks for money and does not give medicines from the hospital examines us. Dharamieet also reported that Government doctors do not give proper treatment. No one pays attention to us. Only private doctors treat us properly".

Case Study VIII :- Saku Bai, aged 42 years, an anganwadi worker at Shahabad said. "Since the Saharia are poor, in case of sickness, they first try herbal remedies and watch for two to three days. If they are not cured then they go to Primary Health 
Centre (PHC) or Sub-Centre (SC) for treatment. The Saharia are not satisfied with the facilities available at the PHC. The doctor gives prescription on paper only and the patients were not given any medicines from PHC. Sometimes the doctors also refuse to see the patients and then the Saharia consult private doctors who pay attention on them. But they have to spend large amount of money on this process. The Saharia are not afraid of immunization. When PHC staff visit their colonies then they get their children immunized." It was found that all the children below one year were immunized.

\section{Impact of Health Programmes on Saharia}

In the Shahabad and Kishangani tehsils, various programmes related to health and medical care have been running in the Primary Health Centres, Sub-Centres and dispensaries. These programmes are: Primary Healthcare, Rural Primary Healthcare Infrastructure, Health Manpower, Control of Communicable Diseases, National Malaria Eradication Programme, Mutipurpose Camps (for ENT diseases, treatment for Handicapped persons, Dental Check-up), National Tuberculosis Programme, National Leprosy Eradication Programme, Control of NonCommunicable Diseases, National Blindness Control Programme, Maternal and Reproductive Health Programme etc. The State and Central Government run some of these programmes.

It may be stated that some of these programmes have been running on the papers and the Saharia were not even aware about these programmes especially in the interior villages. They felt that whenever they contacted the $\mathrm{PHC} / \mathrm{SC} /$ Dispensary/ Health Centres they could not get sufficient information about these programmes. Saharia have been facing lot of problems about their medical treatment and healthcare institutions.

It was observed that Tuberculosis Control Camp is organised on 19th of every month at Kelwara and 23rd of every month at Shahabad. Many Saharia who are suffering from TB attend this camp. Saharia have been given chainit parivar cards when they feel ill they can use these cards and get medicines from the PHC. But when interviewed many Saharia told that when they go to PHC the sister (nurse) or compounder ask Rs.2/- per tablet for cold and headache and if they don't give money to them then the compounder or nurse scolds them and don't give medicines. The Saharia are not afraid of immunization. When PHC Staff visit their villages then they get their children immunized. It was observed that all the children below one year were found immunized at the time of fieldwork. 
The Nasbandi (Tubectomy) camp is organised on 2nd and 4th Friday of every month at PHC, Shahabad. Table 12 presents the monthwise 'Tubectomy' cases among Saharia from April '99' to Jan. 2000 in PHC Shahabad.

It has been observed that maximum percentage of cases of family planning are done in November to January because Saharia females are not busy as they don't have any work to do for economic reasons. They are free and climate also suits them for undergoing operation. During summer the females are busy in various economic activities. In the interior villages the family planning is not much successful when compared to villages in the Upreti because means of communication are not there, absence of ANM due to vacant post and illiteracy. Only women have been found adopting family planning (FP) measures. Males don't adopt FP measures because they think they will become physically weak and will not be able to work.

Table 12. The monthwise 'Tubectomy' Cases Among Saharia from April '99' to Jan. 2000 in PHC Shahabad.

\begin{tabular}{|c|c|c|}
\hline S.No. & Month & No.of Tubectomy Cases \\
\hline 1 & April 1999 & $7(1.17 \%)$ \\
\hline 2 & May 1999 & $1(0.17 \%)$ \\
\hline 3 & June 1999 & $3(0.5 \%)$ \\
\hline 4 & July 1999 & $8(1.33 \%)$ \\
\hline 5 & August 1999 & NIL \\
\hline 6 & September 1999 & $5(0.83 \%)$ \\
\hline 7 & October 1999 & $8(1.33 \%)$ \\
\hline 8 & November 1999 & $68(11.33 \%)$ \\
\hline 9 & December 1999 & $433(72.17 \%)$ \\
\hline 10 & Jan. 2000 (upto 7th Jan.) & $67(11.17 \%)$ \\
\hline Total & & $600(100 \%)$ \\
\hline
\end{tabular}

\section{Conclusion and Suggestions}

The concept that tribals don't accept the modern medical care system is not true. If the facilities are available they are ready to accept it. The above analysis shows that Saharia accept the modern medical care system. They have faith in all the treatments (spiritual, herbal and allopathic).

\section{Acknowledgement}

This study has been support by a research grant from ICSSR to PM and from UGC and University of Delhi to AKK. 


\section{References}

Basu, S.K., [1994]. Health Problems and Health Care of the Tribal Population of India.pp 137-

146. In: Tribal Economy and Wasteland Development. N.Mahanti Ed., New Delhi: Inter-India Publications.

Census of India, [1991]. Rajasthan. District Census Handbook. Kota District. Kota.

Misra P., [1998]. Education in Village Community : An Anthropological Study of Kaya Village in Udaipur District of Rajasthan. MSc. Dissertation (Unpublished), University of Delhi, Delhi.

Misra, P. and Kapoor, A. K., [2001]. Emerging Roles of Medical Anthropology for Health Providers who are Engaged in Tribal Development: A Study among Saharia of Rajasthan. pp. 177-190. In: The Science of Man in the Service of Man M.K.Bhasin and S.L.Malik Eds., Department of Anthropology, University of Delhi, Delhi.

Misra P., [2002]. Ecology, Culture and Health Among Saharia: A Primitive tribe of Rajasthan. Ph.D Thesis (Unpublished), University of Delhi, Delhi.

Misra, P. and Kapoor, A. K., [2002a]. Role of Medical Anthropology in Tribal Development : Future Perspective. pp. 219-236: In: Tribal Welfare and Development: Emerging Roles of Anthropological Explorations. A.N.Sharma Ed., Sarup and Sons: New Delhi.

[2002b]. Environment, Disease Pattern and Health Status in a Primitive Tribe of Rajasthan. pp.3351. In: Eco-Degradation and Population Health: The Challenges and Management in New Millennium. B.N.Pandey Ed., Daya Publishing House : New Delhi.

[2003]. Ethnomedical Practices in a Primitive Tribe. pp.184-215. In: Dimensions of Researches in Indian Anthropology. Vol.1. Vijoy S Sahay \& Pradeep K. Singh. Eds., Serial Publications: New Delhi. 